\section{Urinary tract infection etiology and antimicrobial sensitivity in a Mexican hospital from 2010 to 2015}

\author{
Villalobos-Ayala JL, ${ }^{1}$ Castillo B, ${ }^{2}$ Licea-Serrato JD ${ }^{3}$
}

\begin{abstract}
BACKGROUND: urinary tract infections are common in both community-based and hospitalized patients. The complexity of their management is increasing, as a result of antimicrobial resistance.

OBJECTIVE: to assess the prevalence and antimicrobial susceptibility profile of uropathogens present in urine cultures analyzed at the Hospital Regional ISSSTE, Monterrey, Nuevo Léon, Mexico.
\end{abstract}

MATERIALS AND METHODS: a retrospective cohort study was conducted, based on urine sample analyses performed at the hospital laboratory between January 2010 and September 2015.

RESULTS: data on 4,394 urine cultures were obtained. Escherichia coli was identified in $47.1 \%$ of the isolates. A total of $59.4 \%$ of the Escherichia coli and $59.6 \%$ of the Klebsiella pneumoniae isolates showed production of extended-spectrum beta-lactamases. Candida albicans was found in 3.6\% of the isolates. Most of the Escherichia coli and Klebsiella pneumoniae isolates showed sensitivity to carbapenems.

CONCLUSIONS: these study results provide valuable insight for improving urinary tract infection management at the Hospital Regional ISSSTE of Monterrey. Institutions elsewhere should carry out these investigations, to understand antimicrobial resistance trends in their area of activity and improve their antimicrobial prescription practices.

KEY WORDS: urinary tract infection, UTI, uropathogens, antimicrobial sensitivity

Rev Mex Urol. 2017 mar;77(2):97-105.

\section{Etiología de las infecciones urinarias y sensibilidad antimicrobiana en un hospital mexicano (2010-2015)}

Villalobos-Ayala JL, ${ }^{1}$ Castillo B, ${ }^{2}$ Licea-Serrato $\mathrm{JD}^{3}$

Resumen

ANTECEDENTES: la infección urinaria es frecuente en pacientes ambulatorios y hospitalizados. La complejidad de su tratamiento está aumentando como consecuencia de la resistencia antimicrobiana.
${ }^{1}$ Instituto de Seguridad y Servicios Sociales de los Trabajadores del Estado, Hospital Regional ISSSTE, Department of Urology, Monterrey, Nuevo León, México.

${ }^{2}$ Universidad Autónoma de Nuevo León, Facultad de Odontología, Monterrey, Nuevo León, México ${ }^{3}$ Instituto de Seguridad y Servicios Sociales de los Trabajadores del Estado, Hospital Regional ISSSTE, Department of Infectology, Monterrey, Nuevo León, México.

Received: September 2016

Accepted: February 2017

Correspondence José L. Villalobos-Ayala drvillalobos@uromedics.mx

This article should be cited as Villalobos-Ayala JL, Castillo B, Licea-Serrato JD. Urinary tract infection etiology and antimicrobial sensitivity in a Mexican hospital from 2010 to 2015. Rev Mex Urol. 2017 mar;77(2):97-105. 
OBJETIVO: evaluar en cultivos de orina la prevalencia y perfil de sensibilidad antimicrobiana de los uropatógenos analizados en el Hospital Regional del ISSSTE, Monterrey, Nuevo León, México.

MATERIAL Y MÉTODOS: estudio de cohorte, retrospectivo, de muestras de orina analizadas entre enero de 2010 y septiembre de 2015.

RESULTADOS: se obtuvieron datos de 4394 urocultivos en los que se identificó Escherichia coli en $47.1 \%$ de los aislamientos. El 59.4\% de los aislados de $E$. coli y $59.6 \%$ de los aislados de Klebsiella pneumoniae (K. pneumoniae) mostraron producción de betalactamasas de amplio espectro. Candida albicans se encontró en 3.6\% de los aislamientos. La mayor parte de los aislados de E. coli y de K. pneumoniae mostraron sensibilidad a carbapenémicos.

CONCLUSIONES: estos resultados proporcionan valiosa información para el mejor tratamiento de pacientes con infección de vías urinarias en el Hospital Regional del ISSSTE de Monterrey. Las demás instituciones deberían efectuar estas investigaciones para comprender las tendencias de resistencia antimicrobiana en su área de actividad y, de esta manera, mejorar las prácticas de prescripción de antimicrobianos.

PALABRAS CLAVE: infecciones urinarias, ITU, uropatógenos, sensibilidad antimicrobiana.

\begin{abstract}
${ }^{1}$ Instituto de Seguridad y Servicios Sociales de los Trabajadores del Estado, Hospital Regional ISSSTE, Department of Urology, Monterrey, Nuevo León, México.

${ }^{2}$ Universidad Autónoma de Nuevo León, Facultad de Odontología, Monterrey, Nuevo León, México

${ }^{3}$ Instituto de Seguridad y Servicios Sociales de los Trabajadores del Estado, Hospital Regional ISSSTE, Department of Infectology, Monterrey, Nuevo León, México.
\end{abstract}

\section{Correspondencia}

José L. Villalobos-Ayala

drvillalobos@uromedics.mx

\section{INTRODUCTION}

Urinary tract infections (UTIs) are one of the most commonly diagnosed infections, both in community-based and hospitalized patients. ${ }^{1}$ In the United States, UTIs accounted for 10.5 million outpatient visits in 2007, of which about $21 \%$ corresponded to the emergency department. ${ }^{2}$ In Mexico, UTIs were the third leading cause of morbidity in 2014, with a total of 4,244,053 notified cases. ${ }^{3}$

The financial burden imposed by UTIs is remarkable, especially in Latin American countries, where antimicrobial prescription is less strictly controlled. ${ }^{4} \mathrm{~A}$ cross-sectional study carried out at a pediatric hospital in the Mexican state of Sonora, found that the average cost of medical care per episode of nosocomial UTI was \$2062.00 USD. ${ }^{5}$
In general, women are more affected by UTIs than men. It is estimated that, by the age of 24 , $33 \%$ of women will require antimicrobial treatment for at least one episode of UTI and more than $50 \%$ will experience at least one UTI during their lifetime. ${ }^{6}$ In fact, $75.6 \%$ of the cases of UTI reported in 2008 in Mexico were diagnosed in female patients. ${ }^{7}$

Escherichia coli (E. coli) is the most frequent causative agent of UTIs, accounting for $75 \%$ $95 \%$ of infections. ${ }^{8}$ The remaining episodes are mostly caused by other Enterobacteriaceae, namely Proteus mirabilis (P. mirabilis) and Klebsiella pneumoniae (K. pneumoniae), followed by Gram positive cocci, such as Staphylococcus saprophyticus (S. saprophyticus). ${ }^{8}$ Fungal microorganisms are relatively common uropathogens in nosocomial UTIs. ${ }^{9}$ 
Treatment selection for UTI management is becoming increasingly challenging. Antimicrobial resistance, mostly due to antimicrobial misuse, is on the rise, thus limiting therapeutic options. ${ }^{10}$ The emergence of $E$. coli, as well as of other Enterobacteriaceae that produce extendedspectrum $\beta$-lactamases (ESBLs) is of particular concern, since these enzymes confer resistance to a number of antimicrobials. ${ }^{11}$

The aim of this study was to assess the prevalence of uropathogens identified in urine cultures analyzed at the laboratory of the Hospital Regional ISSSTE of Monterrey, as well as their antimicrobial susceptibility profiles, to help guide therapy selection at the local level.

\section{MATERIALS AND METHODS}

\section{Study design}

This was a non-interventional, retrospective cohort study based on urine sample analysis performed at the laboratory of the Hospital Regional ISSSTE of Monterrey (Nuevo León, Mexico) between January 2010 and September 2015. Information on microbial species and antimicrobial susceptibility was obtained from the laboratory's electronic system.

The urine samples were obtained through sterile urine collection techniques (suprapubic aspiration or collection from catheters). Using a calibrated loop, these samples were inoculated on CLED and MacConkey agar media and incubated at $37^{\circ} \mathrm{C}$.

Only urine cultures considered positive (microbial growth $>10^{5} \mathrm{CFU} / \mathrm{mL}$ ) and exhibiting growth of a single microbial strain were included in this analysis. Each urine culture corresponded to a single patient.

Uropathogen identification and antimicrobial sensitivity testing were performed using the $\mathrm{Vi}$ - tek ${ }^{\circledR} 2$ system (bioMérieux, Inc., Durham, NC, USA) according to the manufacturer's instructions. The Gram-negative (GN), Gram-positive (GP), and Yeast (YST) identification cards and the GP67, GN70, and XL05 antimicrobial susceptibility testing cards were used. Production of ESBLs was also assessed by the Vitek 2 system. Quality control was performed using American Type Culture Collection strains.

The Ethics Committee of the Hospital Regional ISSSTE of Monterrey approved the study, and due to its retrospective design and in compliance with the provisions of Mexican law, written informed consent from the individuals whose urine samples were analyzed was not required.

\section{Statistical analysis}

Descriptive statistics (absolute and relative frequencies, as applicable) were used to summarize the data on uropathogen identification and the antimicrobial sensitivity of the isolates.

\section{RESULTS}

Data on 4,394 positive urine cultures were obtained for analysis. The most frequently isolated uropathogen was $E$. coli, which was identified in $47.1 \%$ of the cultures (Table 1 ).

The most common uropathogens after $E$. coli were Enterococcus faecalis (E. faecalis) and Pseudomonas aeruginosa ( $P$. aeruginosa), which were isolated in $13.2 \%$ and $10.2 \%$ of the cultures, respectively. $K$. pneumoniae, the second most frequently identified Gram-negative bacterium, was found in 410 (9.33\%) urine cultures. Among the fungal species, Candida albicans (C. albicans) was the most common, identified in $3.6 \%$ of the urine cultures.

E. coli and K. pneumoniae were the ESBL-producing uropathogens found in the urine cultures 
Table 1. Frequency of uropathogens in urine cultures of patients at the Hospital Regional ISSSTE of Monterrey (Nuevo Léon, Mexico) between January 2010 and September 2015

\begin{tabular}{|l|c|}
\hline Microorganism & $\begin{array}{c}\text { No. of isolates (\%) } \\
(\mathbf{n}=\mathbf{4 3 9 4})\end{array}$ \\
\hline Gram-negative bacteria & $2070(47.1)$ \\
\hline Escherichia coli & $410(9.3)$ \\
\hline Klebsiella pneumoniae & $450(10.2)$ \\
\hline Pseudomonas aeruginosa & $115(2.6)$ \\
\hline Enterobacter cloacae & $113(2.6)$ \\
\hline Proteus mirabilis & $42(1.0)$ \\
\hline Acinetobacter baumannii & $582(13.2)$ \\
\hline Gram-positive bacteria & $155(3.5)$ \\
\hline Enterococcus faecalis & $52(1.2)$ \\
\hline Enterococcus faecium & $44(1.0)$ \\
\hline Staphylococcus haemolyticus & $40(0.9)$ \\
\hline Staphylococcus aureus & \\
\hline Staphylococcus epidermidis & $158(3.6)$ \\
\hline Fungi & $82(1.9)$ \\
\hline Candida albicans & $81(1.8)$ \\
\hline Candida glabrata & \\
\hline Candida tropicalis & \\
\hline
\end{tabular}

and they presented similar prevalences: $59.4 \%$ and $59.6 \%$, respectively (Table 2 ).

The sensitivity of the isolated Gram-negative bacteria varied widely across antimicrobial classes (Table 3).

Table 2. Frequency of ESBL-producing uropathogens in urine cultures of patiens at the Hospital Regional ISSSTE of Monterrey (Nuevo Léon, Mexico) between January 2010 and September 2015

\begin{tabular}{|l|c|}
\hline Microorganism & $\begin{array}{c}\text { No. of ESBL-producing } \\
\text { isolates (\%) }\end{array}$ \\
\hline Escherichia coli & $1229(59.4)$ \\
\hline Klebsiella pneumoniae & $244(59.6)$ \\
\hline
\end{tabular}

ESBL: Extended spectrum beta-lactamase
Carbapenems were the most active antimicrobial agents against $E$. coli, with $100 \%$ of the isolates showing sensitivity to both imipenem and meropenem and $99.6 \%$ displaying sensitivity to ertapenem. The majority of $E$. coli isolates were also very sensitive to tigecycline $(99.8 \%)$ and amikacin (98.5\%).

K. pneumoniae presented a similar sensitivity pattern, also in its range of sensitivity to the various cephalosporins. However, more isolates of $K$. pneumoniae than E. coli were sensitive to ampicillin/sulbactam ( $51.8 \%$ vs. $28.2 \%$, respectively).

As did E. coli and K. pneumoniae, P. mirabilis isolates showed a degree of sensitivity to all antimicrobials, with the exception of colistin.

A generally low proportion of $P$. aeruginosa isolates presented with sensitivity to the antimicrobials studied herein. Nevertheless, $71.9 \%$ of the isolates were sensitive to piperacillin/ tazobactam.

Gentamicin, ciprofloxacin, moxifloxacin, and vancomycin were the only antimicrobials to which a proportion of all species of Grampositive bacteria were sensitive (Table 4). One hundred percent of the isolates of all the species, except Staphylococcus epidermidis ( $S$. epidermidis), were sensitive to tigecycline. Nitrofurantoin also showed good action against these bacteria, excluding Enterococcus faecium (E. faecium).

In general, the isolated fungal species presented good sensitivity to the antifungals analyzed (Table 5). Candida tropicalis (C. tropicalis) isolates, in particular, were all sensitive to the four antifungals. One hundred percent of $C$. albicans isolates were sensitive to fluconazole and voriconazole. The majority of Candida glabrata ( $C$. glabrata) isolates were sensitive to flucytosine $(96.3 \%)$. 
Villalobos-Ayala JL y col. Urinary tract infection etiology and antimicrobial sensitivity

Table 3. Proportion of Gram-negative bacteria isolates with sensitivity to the selected antimicrobials

\begin{tabular}{|c|c|c|c|c|c|c|}
\hline \multirow[b]{2}{*}{ Antimicrobial classes } & \multicolumn{6}{|c|}{ Gram-negative bacteria } \\
\hline & $\begin{array}{c}\text { Escherichia } \\
\text { coli, } \\
\%(\mathrm{n}=2070)\end{array}$ & $\begin{array}{c}\text { Pseudomonas } \\
\text { aeruginosa, } \\
\%(n=450)\end{array}$ & $\begin{array}{c}\text { Klebsiella } \\
\text { pneumoniae, } \\
\%(n=410)\end{array}$ & $\begin{array}{c}\text { Enterobacter } \\
\text { cloacae, } \\
\%(n=115)\end{array}$ & $\begin{array}{c}\text { Proteus } \\
\text { mirabilis, } \\
\%(\mathrm{n}=113)\end{array}$ & $\begin{array}{c}\text { Acinetobacter } \\
\text { baumannii, } \\
\%(\mathrm{n}=42)\end{array}$ \\
\hline
\end{tabular}

Penicillins

\begin{tabular}{|c|c|c|c|c|c|c|}
\hline Ampicillin & 21.1 & 0.0 & 4.3 & 14.7 & 52.3 & 0.0 \\
\hline \multicolumn{7}{|c|}{ Penicillins/ß-lactamase inhibitor } \\
\hline Ampicillin/Sulbactam & 28.2 & 0.0 & 51.8 & 0.0 & 82.2 & 33.5 \\
\hline Piperacillin/Tazobactam & 83.9 & 71.9 & 81.8 & 25.7 & 92.3 & 17.4 \\
\hline \multicolumn{7}{|l|}{ Cephalosporins } \\
\hline Cefazolin & 54.2 & 0.0 & 58.0 & 0.0 & 67.3 & 0.0 \\
\hline Cefepime & 46.7 & 25.6 & 60.8 & 42.8 & 68.3 & 18.9 \\
\hline Ceftriaxone & 57.3 & 0.2 & 59.4 & 25.3 & 69.1 & 7.1 \\
\hline \multicolumn{7}{|l|}{ Aminoglycosides } \\
\hline Amikacin & 98.5 & 33.0 & 91.7 & 57.9 & 97.3 & 76.1 \\
\hline Gentamicin & 68.4 & 30.3 & 75.1 & 56.0 & 85.5 & 32.4 \\
\hline Tobramycin & 55.3 & 30.9 & 65.0 & 47.2 & 85.8 & 24.6 \\
\hline \multicolumn{7}{|l|}{ Streptomycin } \\
\hline \multicolumn{7}{|l|}{ Fluoroquinolones } \\
\hline Ciprofloxacin & 34.3 & 19.5 & 68.5 & 35.2 & 92.8 & 21.3 \\
\hline Moxifloxacin & 33.4 & 15.6 & 69.6 & 37.5 & 88.4 & 11.8 \\
\hline \multicolumn{7}{|l|}{ Carbapenems } \\
\hline Ertapenem & 99.6 & 0.0 & 96.8 & 76.6 & 94.5 & 0.0 \\
\hline Imipenem & 100.0 & 22.6 & 97.3 & 94.1 & NA & 22.8 \\
\hline Meropenem & 100.0 & 28.9 & 98.1 & 93.1 & 95.4 & 23.8 \\
\hline \multicolumn{7}{|l|}{ Other antimicrobials } \\
\hline Nitrofurantoin & 82.9 & 0.0 & 8.8 & 13.9 & 7.3 & 0.0 \\
\hline Tigecycline & 99.8 & 0.4 & 86.3 & 58.6 & 31.1 & 31.0 \\
\hline TMP/SMX & 42.5 & 0.8 & 62.3 & 28.8 & 56.8 & 11.0 \\
\hline Colistin & 0.0 & 30.0 & 0.0 & 0.0 & 0.0 & 40.6 \\
\hline Aztreonam & 57.7 & 14.6 & 45.9 & 32.8 & 63.0 & 2.3 \\
\hline
\end{tabular}

NA: Not available

TMP/SMX: Trimethoprim/Sulfamethoxazole

\section{DISCUSSION}

The most commonly isolated uropathogen in this sample of urine cultures was $E$. coli, accounting for $47.1 \%$ of all isolated microorganisms. This finding is consistent with numerous studies that have shown this bacterium to be the most important etiologic agent of UTI worldwide. , $^{812-14}$ In Mexico, this trend has been observed in both adult and pediatric populations, with local studies reporting frequencies of $E$. coli isolates ranging from $41 \%$ to $79 \% .^{15-18}$ 
Table 4. Proportion of Gram-positive bacteria isolates with sensitivity to selected antimicrobials

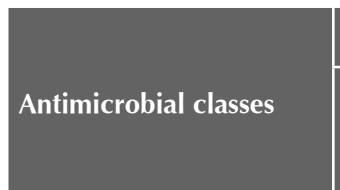

\begin{tabular}{|c|c|c|c|}
\hline \multicolumn{4}{|c|}{ Gram-positive bacteria } \\
\hline Enterococcus & Enterococcus & Staphylococcus & Staphylococcus \\
faecalis, & faecium, & haemolyticus, & aureus, \\
$\%(n=582)$ & $\%(n=155)$ & $\%(n=52)$ & $\%(n=44)$ \\
\hline
\end{tabular}

Staphylococcus

epidermidis,

$\%(n=40)$

Penicillins

\begin{tabular}{|c|c|c|c|c|c|}
\hline Ampicillin & 62.1 & 13.3 & 0.0 & 0.0 & 0.0 \\
\hline Benzylpenicillin & 62.1 & 0.0 & 0.0 & 2.3 & 0.0 \\
\hline \multicolumn{6}{|l|}{ Aminoglycosides } \\
\hline Gentamicin & 33.4 & 22.6 & 47.9 & 82.6 & 44.9 \\
\hline Streptomycin & 47.0 & 43.5 & 0.0 & 0.0 & 0.0 \\
\hline \multicolumn{6}{|l|}{ Fluoroquinolones } \\
\hline Ciprofloxacin & 43.9 & 8.4 & 32.6 & 52.3 & 47.7 \\
\hline Moxifloxacin & 43.4 & 11.2 & 50.1 & 56.8 & 72.4 \\
\hline Levofloxacin & 44.8 & 0.0 & 5.8 & $(54.5$ & 47.7 \\
\hline \multicolumn{6}{|l|}{ Other antimicrobials } \\
\hline Nitrofurantoin & 96.3 & 0.0 & 100.0 & 100.0 & 100.0 \\
\hline Tigecycline & 100.0 & 100.0 & 100.0 & 100.0 & 0.0 \\
\hline TMP/SMX & 0.0 & 0.0 & 28.7 & 86.4 & 41.7 \\
\hline Vancomycin & 98.8 & 65.9 & 98.0 & 97.8 & 80.0 \\
\hline Linezolid & 96.8 & 88.2 & 100.0 & 0.0 & 100.0 \\
\hline Tetracycline & 35.1 & 71.7 & 0.0 & 95.5 & 87.6 \\
\hline Colistin & 0.0 & 0.0 & 9.6 & 0.0 & 0.0 \\
\hline Clindamycin & 0.0 & 0.0 & 51.9 & 54.7 & 72.5 \\
\hline Rifampicin & 0.0 & 0.0 & 94.1 & 95.5 & 100.0 \\
\hline Erythromycin & 15.5 & 0.0 & 23.2 & 50.2 & 67.7 \\
\hline
\end{tabular}

Table 5. Proportion of fungi isolates with sensitivity to the selected antimicrobials

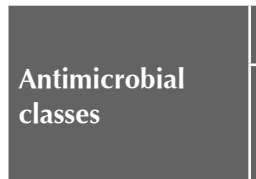

\begin{tabular}{|c|c|c|}
\hline \multicolumn{3}{|c|}{ Fungi } \\
\hline $\begin{array}{c}\text { Candida } \\
\text { albicans }\end{array}$ & $\begin{array}{c}\text { Candida } \\
\text { glabrata }\end{array}$ & $\begin{array}{c}\text { Candida } \\
\text { tropicalis } \\
\%\end{array}$ \\
$\%$ & $\%$ \\
\hline
\end{tabular}

Antifungals

\begin{tabular}{lccc} 
Amphotericin B & 96.0 & 89.8 & 100.0 \\
\hline Flucytosine & 99.3 & 96.3 & 100.0 \\
\hline Fluconazole & 100.0 & 79.4 & 100.0 \\
Voriconazole & 100.0 & 87.6 & 100.0
\end{tabular}

After E. coli, the most frequently isolated microorganisms were $E$. faecalis (13.2\%), P. aeruginosa $(10.2 \%)$, and K. pneumoniae $(9.3 \%)$, with preva- lences similar to those reported elsewhere in Latin America. ${ }^{12,15,18}$

More than half of the $E$. coli isolates (59.4\%), as well as of the K. pneumoniae isolates (59.6\%), showed ESBL production. A similar prevalence of ESBL-producing K. pneumoniae (53.3\%) was found by Flam et al. across 16 Latin American medical centers. However, the prevalence of ESBL-producing E. coli reported by those authors $(37.6 \%)$ was lower than ours. ${ }^{19}$

The high rates of ESBL-producing bacteria identified in our sample are cause for concern. In the past, the majority of ESBL-producing 
bacteria were isolated from hospitalized patients, but recent data have shown that ESBL production by common, community-acquired uropathogens, such as $E$. coli, has markedly increased. ${ }^{20-21}$ This has also been reported in Latin America., ${ }^{414}$ ESBL-producing bacteria often show co-resistance to various antimicrobial drug classes (e.g. penicillins, cephalosporins, trimethoprim/sulfamethoxazole [TMP/SMX], among others). ${ }^{22-23}$ This issue is further complicated by the fact that these agents frequently cause serious invasive infections and are associated with a worse prognosis. ${ }^{24}$

In the present study, fungi were isolated in 321 urine cultures. Isolation frequency, specifically of C. albicans (3.6\%), was lower than that reported in other studies, ${ }^{25-28}$ which could be explained by differences between study populations.

In our sample, almost half (42.5\%) of the E.coli isolates were sensitive to TMP/SMX. The number of isolates sensitive to fluoroquinolones was lower (ciprofloxacin: 34.3\%; moxifloxacin: $33.4 \%)$. Fluoroquinolones have been prescribed empirically when there is clinical suspicion of UTI, due to the known, widespread resistance to TMP/SMX. It appears, however, that such frequent use has compromised their efficacy. ${ }^{29}$

Overall, the number of $E$. coli and K. pneumoniae isolates sensitive to the antimicrobials tested was low. This could be explained by the high prevalence of ESBL-producing isolates of both species. Nevertheless, the sensitivity of these Enterobacteriaceae to carbapenems was high, with over $95 \%$ of the isolates of each species showing sensitivity to all the tested antimicrobials of this class. This is in accordance with the findings of the SENTRY and SMART surveillance programs. ${ }^{12,14}$ Indeed, carbapenems have been identified as the antimicrobials of choice for infections caused by ESBL-producing microorganisms. ${ }^{30}$ However, caution should be used, given that carbapenem resistance is reportedly increasing. ${ }^{24}$

Isolates of $P$. aeruginosa, which is a frequent etiologic agent of nosocomial infections, ${ }^{31}$ showed overall low sensitivity to the antimicrobials listed. Concerns over infections caused by drug-resistant $P$. aeruginosa are not new. A 5-year analysis of $P$. aeruginosa susceptibility rates in Latin American centers participating in the SENTRY surveillance program showed rapidly increasing resistance to common antipseudomonal agents, especially meropenem (from $83.0 \%$ in 1997 to $64.4 \%$ in $2001, p<0.001) .^{32}$

The antimicrobials that exerted the most action on Gram-positive bacteria were nitrofurantoin and tigecycline, with $100 \%$, or nearly $100 \%$, of the isolates showing sensitivity to them (except those of E. faecium and S. epidermidis, respectively). Nitrofurantoin is still rarely used for the empirical treatment of UTIs. Its spectrum of susceptible organisms has remained virtually unchanged, with little evidence of resistance emergence, despite its being on the market for over 60 years. ${ }^{33}$ Nitrofurantoin might therefore be considered an interesting alternative for the treatment of UTIs caused by multi-drug resistant microorganisms. ${ }^{34}$

Tigecycline also presents strong antimicrobial activity against both Gram-positive and Gram-negative bacteria. Data on antimicrobial susceptibility of microorganisms collected in Mexico between 2005 and 2012 show 100\% tigecycline susceptibility reported among isolates of Enterococcus sp. and S. aureus, ${ }^{35}$ which was similar to what we found. Jones et al. reported identical susceptibility rates in their 2011 analysis of Latin American isolates. ${ }^{36}$

Nearly $100 \%$ of the isolates of every fungal species identified in the present sample were sensitive to the antifungals tested. Nonetheless, it is worth 
noting that fungi in urine cultures are often asymptomatic and may not require pharmacologic treatment. Eliminating the elements that facilitate colonization, such as indwelling catheters, may suffice. ${ }^{37}$ Fluconazole has been the recommended treatment option, when applicable. ${ }^{38-39}$

Antimicrobial sensitivities show great geographic variability. Therefore, the present study is limited by the fact that our sample came from a single institution. Each institution should be aware of the relevance of collecting this type of information to better guide therapy selection for UTIs and implement control strategies for any antimicrobial resistance patterns identified.

Moreover, because the hospital laboratory system did not contain such information, it was not possible to assess relationships between uropathogen frequencies and the antimicrobial sensitivity of the isolates to factors such as sex, infection origin, type of UTI, or presence of risk factors, among others.

\section{CONCLUSIONS}

The results presented herein provide additional evidence in relation to the role of different microorganism species as etiologic agents of UTIs. Furthermore, they provide valuable antimicrobial sensitivity information that will help guide antimicrobial selection for the treatment of UTIs diagnosed at the Hospital Regional ISSSTE of Monterrey, in Mexico.

Implementation of the appropriate public health actions (e.g. antimicrobial susceptibility surveillance) is necessary to better understand the patterns of antimicrobial sensitivity in Mexico and thus aid in the appropriate decision-making regarding their prescription in clinical practice. This, in turn, is essential for preventing the spread of resistance mechanisms and for reducing direct healthcare costs associated with UTIs.

\section{REFERENCES}

1. Foxman B. Urinary tract infection syndromes: occurrence, recurrence, bacteriology, risk factors, and disease burden. Infect Dis Clin North Am. 2014 Mar;28:1-13.

2. Schappert SM, Rechtsteiner EA. Ambulatory medical care utilization estimates for 2007. Vital Health Stat. 2011;13:1-38

3. Dirección General de Epidemiología de México. Distribución de casos nuevos de enfermedad por grupos de edad. Estados Unidos Mexicanos 2014. Población General. 2014 [cited 2016 Apr 14]. Available from: http://www. epidemiologia.salud.gob.mx/anuario/2014/morbilidad/ nacional/distribucion_casos_nuevos_enfermedad_grupo_edad.pdf

4. Bours PHA, Polak R, Hoepelman AIM, et al. Increasing resistance in community-acquired urinary tract infections in Latin America, five years after the implementation of national therapeutic guidelines. Int J Infect Dis. 2010;14:e770-4.

5. Álvarez-Hernández G, Amaro-Ortega C. Costos atribuibles y factores de riesgo de infección nosocomial en un Hospital Pediátrico del Estado de Sonora, 2008. Bol Méd Hosp Infant México. 2010;67:118-27.

6. Foxman B. Epidemiology of Urinary Tract Infections: Incidence, Morbidity, and Economic Costs. Dis Mon. 2003;49:53-70.

7. Sistema Nacional de Vigilancia Epidemiológica. Panorama Epidemiológico de las Infecciones de Vías Urinarias en México 2003-2008. 2009 [cited 2016 Apr 14]. Available from: http://www.epidemiologia.salud.gob.mx/doctos/ boletin/2009/sem51.pdf

8. Gupta K, Hooton TM, Naber KG, et al. International clinical practice guidelines for the treatment of acute uncomplicated cystitis and pyelonephritis in women: A 2010 update by the Infectious Diseases Society of America and the European Society for Microbiology and Infectious Diseases. Clin Infect Dis. 2011;52:e103-20.

9. Bouza E, San Juan R, Muñoz P, et al. A European perspective on nosocomial urinary tract infections II. Report on incidence, clinical characteristics and outcome (ESGNI-004 study). European Study Group on Nosocomial Infection. Clin Microbiol Infect. 2001;7:532-42.

10. Grigoryan L, Trautner BW, Gupta K. Diagnosis and management of urinary tract infections in the outpatient setting: a review. JAMA. 2014;312:1677-84.

11. Boyle DP, Zembower TR. Epidemiology and Management of Emerging Drug-Resistant Gram-Negative Bacteria: Extended-Spectrum $\beta$-Lactamases and Beyond. Urol Clin North Am. 2015;42:493-505.

12. Gales AC, Sader HS, Jones RN, et al. Urinary tract infection trends in Latin American hospitals: report from the SENTRY antimicrobial surveillance program (1997-2000). Diagn Microbiol Infect Dis. 2002;44:289-99. 
13. Gales AC, Jones RN, Gordon KA, Sader HS, et al. Activity and spectrum of 22 antimicrobial agents tested against urinary tract infection pathogens in hospitalized patients in Latin America: report from the second year of the SENTRY antimicrobial surveillance program (1998). J Antimicrob Chemother. 2000;45:295-303.

14. Morrissey I, Hackel M, Badal R, et al. A Review of Ten Years of the Study for Monitoring Antimicrobial Resistance Trends (SMART) from 2002 to 2011. Pharm Basel Switz. 2013;6:1335-46.

15. Cornejo-Juárez P, Velásquez-Acosta $C$, Sandoval S, et al. Patrones de resistencia bacteriana en urocultivos en un hospital oncológico. Salud Pública México. 2007 Oct;49:330-6.

16. López-Martínez B, Calderón-Jaimes E, Olivar-López V, et al. Susceptibilidad antimicrobiana de microorganismos causantes de infección de vías urinarias bajas en un hospital pediátrico. Bol Méd Hosp Infant México. 2014;71:339-45.

17. García-Morúa A, Hernández-Torres A, Salazar-de-Hoyos JL, et al. Community-acquired urinary tract infection etiology and antibiotic resistance in a Mexican population group. Rev Mex Urol. 2009;69:45-8.

18. Arreguín V, Cebada M, Simón Jl, et al. Microbiología de las infecciones urinarias en pacientes ambulatorios. Opciones terapéuticas en tiempos de alta resistencia a los antibiótico. Rev Investig Clínica. 2007;59:239-45.

19. Flamm RK, Sader HS, Jones RN. Ceftaroline activity tested against contemporary Latin American bacterial pathogens (2011). Braz J Infect Dis. 2014;18:187-95

20. Pitout JDD, Nordmann P, Laupland KB, et al. Emergence of Enterobacteriaceae producing extended-spectrum beta-lactamases (ESBLs) in the community. J Antimicrob Chemother. 2005;56:52-9.

21. Nakai $\mathrm{H}$, Hagihara $\mathrm{M}$, Kato $\mathrm{H}$, et al. Prevalence and risk factors of infections caused by extended-spectrum $\beta$-lactamase (ESBL)-producing Enterobacteriaceae. J Infect Chemother. 2016;22:319-26.

22. Franiczek R, Krzyzanowska B, Dolna I, et al. Extended-spectrum beta-lactamase-conferring transferable resistance to different antimicrobial agents in Enterobacteriaceae isolated from bloodstream infections. Folia Microbiol (Praha). 2005;50:119-24.

23. Franiczek R, Dolna I, Krzyzanowska B. Transferable resistance to different antimicrobials due to CTX-M-type $\beta$-lactamases among Citrobacter freundii, Serratia marcescens, and Enterobacter spp. clinical isolates. Adv Clin Exp Med. 2007;16(4):493-500.

24. Rodríguez-Baño J, Navarro MD, Ngugro MD. Extendedspectrum beta-lactamases in ambulatory care: a clinical perspective. Clin Microbiol Infect. 2008;14 Suppl 1:104-10.

25. Ozhak-Baysan B, Ogunc D, Colak D, et al. Distribution and antifungal susceptibility of Candida species causing nosocomial candiduria. Med Mycol. 2012;50:529-32.
26. Kauffman CA, Vazquez JA, Sobel JD, et al. Prospective multicenter surveillance study of funguria in hospitalized patients. The National Institute for Allergy and Infectious Diseases (NIAID) Mycoses Study Group. Clin Infect Dis. 2000 Jan;30:14-8.

27. Aubron C, Suzuki S, Glassford NJ, et al. The epidemiology of bacteriuria and candiduria in critically ill patients. Epidemiol Infect. 2015;143:653-62.

28. Padawer D, Pastukh N, Nitzan O, et al. Catheter-associated candiduria: Risk factors, medical interventions, and antifungal susceptibility. Am J Infect Control. 2015;43:e19-22.

29. Chen $\mathrm{Y}-\mathrm{H}, \mathrm{Ko} \mathrm{W}-\mathrm{C}, \mathrm{H}$ sueh P-R. The role of fluoroquinolones in the management of urinary tract infections in areas with high rates of fluoroquinolone-resistant uropathogens. Eur J Clin Microbiol Infect Dis. 2012;31:1699-704.

30. Pitout JDD, Laupland KB. Extended-spectrum betalactamase-producing Enterobacteriaceae: an emerging public-health concern. Lancet Infect Dis. 2008;8:159-66.

31. Chatterjee M, Anju CP, Biswas L, et al. Antibiotic resistance in Pseudomonas aeruginosa and alternative therapeutic options. Int J Med Microbiol. 2016 Jan;306:48-58.

32. Andrade SS, Jones RN, Gales AC, et al. Increasing prevalence of antimicrobial resistance among Pseudomonas aeruginosa isolates in Latin American medical centres: 5 year report of the SENTRY Antimicrobial Surveillance Program (1997-2001). J Antimicrob Chemother. 2003;52:140-1.

33. Cunha BA, Schoch PE, Hage JR. Nitrofurantoin: Preferred Empiric Therapy for Community-Acquired Lower Urinary Tract Infections. Mayo Clin Proc. 2011;86:1243-4.

34. Munoz-Davila MJ. Role of Old Antibiotics in the Era of Antibiotic Resistance. Highlighted Nitrofurantoin for the Treatment of Lower Urinary Tract Infections. Antibiotics. 2014;3:39-48.

35. Morfin-Otero R, Noriega ER, Dowzicky MJ. Antimicrobial susceptibility trends among gram-positive and -negative clinical isolates collected between 2005 and 2012 in Mexico: results from the Tigecycline Evaluation and Surveillance Trial. Ann Clin Microbiol Antimicrob. 2015;14:53.

36. Jones RN, Guzman-Blanco M, Gales AC, et al. Susceptibility rates in Latin American nations: report from a regional resistance surveillance program (2011). Braz J Infect Dis. 2013;17:672-81.

37. Kauffman CA. Diagnosis and management of fungal urinary tract infection. Infect Dis Clin North Am. 2014;28:61-74.

38. Thomas L, Tracy CR. Treatment of Fungal Urinary Tract Infection. Urol Clin North Am. 2015;42:473-83.

39. Chaari A, Ismail M, Abdel Hakim K, et al. Effectiveness of Systemic Fluconazole in Adult Patients With Asymptomatic Candiduria: A Systematic Review and Meta-Analysis. Am J Ther. 2016. 